\title{
Pengaruh AIS dan Pipa Gas Buang Berbahan Tembaga dan Aluminium terhadap Mesin 200cc
}

\author{
Dimitrij Chrisna Al Franzleon ${ }^{1)}$, Dikky Antonius ${ }^{2)}$ Priyono Atmadi ${ }^{3)}$ \\ ${ }^{1,2,3)}$ Program Studi Teknik Mesin Universitas Kristen Indonesia \\ Jalan Maydjen Sutoyo No.2, Jakarta Timur 13650 \\ Email: alfranzleon@gmail.com; dicky.antonius@uki.ac.id, priyono.atmadi@gmail.com
}

doi: https://doi.org/10.24843/METTEK.2021.v07.i01.p04

\begin{abstract}
Abstrak
Perkembangan teknologi otomotif dewasa ini semakin pesat.. Dengan meningkatnya populasi kendaraan bermotor akan berdampak pada peningkatan polusi dan konsumsi bahan bakar minyak (BBM). Jenis penelitian ini adalah eksperimen, obyek penelitian adalah mobil Motor Roda 3 Merk Powerace $200 \mathrm{cc}$, bahan bakar yang digunakan adalah pertalite. Dengan menggunakan putaran mesin $1500 \mathrm{rpm}$ sampai 4500 Penelitian ini menggunakan pipa gas buang berbahan logam non ferro ( tembaga dan aluminium) dan penambahan komponen AIS. Teknik analisis yang digunakan adalah analisis deskriptif yaitu mendeskripsikan data numerik yang diperoleh dari pengujian yang telah dilakukan, kemudian dijelaskan dalam bentuk kalimat sederhana yang mudah dipahami. Berdasarkan hasil penelitian dapat disimpulkan bahwa penggunaan pipa gas buang dengan bahan non ferro dan penambahan komponen AIS pada sisttem pembakaran mesin memberikan dampak terhadap gas $\mathrm{CO}, \mathrm{CO}_{2}, \mathrm{HC}$, dan NOx. Rata - rata gas $\mathrm{CO}$ terendah didapatkan pada tipe uji 3 yaitu sebesar $0.017 \%$, untuk gas $\mathrm{CO}_{2}$ paling baik di dapatkan tipe uji 3 yaitu sebesar $7.3 \%$ yang menandakan pembakaran lebih sempurna, untuk gas HC nilai rata - rata terendah dihasilkan dari tipe uji 3 yaitu sebesar $53.7 \mathrm{ppm}$, dan gas NOx terbaik dihasilkan dari tipe uji 4 yaitu sebesar 50,7 ppm, sedangkan untuk pengguaan bahan bakar paling rendah di dapatkan dari tipe uji 3 dengan konsumsi bahan bakar 0,4 $\mathrm{L} / \mathrm{h}$.
\end{abstract}

Kata kunci: pipa gas buang, air induction system, emisi gas buang, konsumsi bahan bakar, sepeda motor 4 langkah $200 \mathrm{cc}$, roda 3.

\begin{abstract}
The development of automotive technology today is growing rapidly. The increasing population of motorized vehicles will have an impact on increasing pollution and consumption of fuel oil (BBM). This type of research is an experiment, the object of research is a 200cc Powerace 3-wheeled motorcycle, the fuel used is pertalite. By using an engine speed of $1500 \mathrm{rpm}$ to 4500 This research uses exhaust gas pipes made of nonferrous metals (copper and aluminum) and the addition of AIS components. The analysis technique used is descriptive analysis, which describes the numerical data obtained from the tests that have been carried out, then explained in the form of simple sentences that are easy to understand. Based on the research results, it can be concluded that the use of exhaust pipes with non-ferrous materials and the addition of AIS components to the engine combustion system has an impact on $\mathrm{CO}, \mathrm{CO} 2, \mathrm{HC}$, and $\mathrm{NOx}$ gases. The lowest average CO gas was obtained in type 3, which was $0.017 \%$, for CO2 gas, it was best to get type 3, which was $7.3 \%$, which indicates a more complete combustion, for HC gas the lowest average value was obtained from type 3, namely amounted to $53.7 \mathrm{ppm}$, and the best NOx gas was produced from type 4, which was 50.7 ppm, while for the use of the lowest fuel obtained from test type 3 with a fuel consumption of $0.4 \mathrm{~L} / \mathrm{h}$.
\end{abstract}

Keywords: exhaust pipe, water induction system, exhaust emission, fuel consumption, 200cc 4 stroke motorcycle, 3 wheels.

Penulis korespondensi,

Email: alfranzleon@gmail.com 


\section{PENDAHULUAN}

Peningkatan jumlah kendaraan yang terjadi dari tahun 2014 sampai 2018 adalah sebanyak 27.124.807 unit [1] hal ini menyebabkan peningkatan polusi. teknologi yang dapat digunakan untuk mereduksi gas $\mathrm{CO}, \mathrm{HC}$, Nox serta membantu unjuk kerja mesin pada kendaraan adalah dengan pemasangan komponen Catalytic Converter, modifikasi sudut intake manifold, pemasangan Hydro Carbon System (HCS), dan pemasangan Air Induction System (AIS).

Beberapa penelitian tentang analisa unjuk kerja mesin 4 langkah telah dilakukan untuk bisa mengoptimalkan sistem kerja mesin.. Andi Sanata1, Imam Sholahuddin2 [2] yang meneliti penggunaan pipa baja dengan kandungan karbon rendah sebagai catalytic converter serta penambahan gas elpiji untuk menganalisa kadar gas buang yang dihasilkan oleh sepeda motor 4 langkah $125 \mathrm{cc}$. penelitian tersebut menunjukkan bahwa perancangan catalytic converter baja karbon rendah yang disusun dengan sistem honeycomb berpengaruh terhadap penurunan emisi gas CO sebesar 50\% jika dibandingkan dengan kondisi standar dan memiliki penggunaan bahan bakar yang lebih hemat. Majanasastra, Raden Bagus Suryasa, dkk [3] melakukan penelitian terhadap performa mesin motor 4 langkah berbahan bakar premium menggunakan pipa Hydrocarbon Cracking System (HCS) berbahan tembaga dengan variasi ukuran yang berbeda untuk mengukur penghematan bahan bakar dan mengukur torsi yang dihasilkan dengan variasi ukuran yaitu $300 \mathrm{~mm}, 450 \mathrm{~mm}, 500 \mathrm{~mm}$ dengan diameter $2 \mathrm{~mm}$. Panjang HCS $550 \mathrm{~mm}$ menghasilkan torsi tertinggi dan Penghematan bahan bakar tertinggi pada putaran $7000 \mathrm{rpm}$. Irawan, dkk [4] melakukan penelitian dengan komponen Air Induction System (AIS). Penggunaan komponen AIS ini dapat menurunkan konsumsi bahan bakar sebesar 26,03\% pada putaran tertentu, dan dapat menurunkan emisi gas CO sebesar 20\% dari kondisi normal

Selain modifikasi komponen tambahan yang ada pada kendaraan bermotor, ternyata variasi dari diameter pipa saluran gas buang memberikan dampak yang berbeda pula terhadap torsi dan daya yang dihasilkan, hal ini dibuktikan dari penelitian Sefnath, dkk [5] yang melakukan kajian simulasi terhadap variasi pipa exhaust manifold. Pada penelitian ini dilakukan pengetesan unjuk torsi dan daya mesin dengan menggunakan variasi ukuran $25 \mathrm{~mm}$, $23 \mathrm{~mm}, 24 \mathrm{~mm}, 25 \mathrm{~mm}$. kesimpulan dari penelitian ini adalah setiap diameter memiliki hasil yang berbeda - beda terutama pada putaran tertentu dari mesin, torsi dan daya maksimum dihasilkan pada diameter $24 \mathrm{~mm}$, ini terjadi karena tekanan balik yang dihasilkan dari kerja mesin tersebut mencapai titik ideal pada diameter tersebut.

Penelitian lebih lanjut terkait emisi juga dilakukan Muchamad Sudjada dan tim [6] yang melakukan penelitian pada kendaraan roda dua 135 cc yang dilengkapi dengan Air Induction System dan ditambah komponen catalytic converter berbahan $\mathrm{CuCr}$ yang mempunyai tinggi lekukan bervariasi, yaitu $3 \mathrm{~mm}$, $5 \mathrm{~mm}$, dan $7 \mathrm{~mm}$. Variabel yang diteliti yaitu emisi gas buang khususnya kadar gas HC dengan rata - rata reduksi sebesar 36,49\%, 23,36\% dan $11,36 \%$., dan CO rata-rata sebesar $58,19 \%, 55,11 \%$ dan 46,33\%. Terjadi penurunan kadar gas dengan adanya variasi dari lekukan catalytic tersebut jika dibandingkan dengan kondisi normal. Hal ini disebabkan karena adanya proses penyerapan terhadap komponen polutan dari gas buang dan oksigen dipermukaan katalis, sehingga menyebabkan melemahnya ikatan atom - atom pada gas buang tersebut yang menyebabkan reaksi antar atom menjadi lebih mudah dan lebih cepat.

Dalam penelitian haryanto, dkk [7] menyatakan bahwa beberapa bahan yang diketahui sebagai katalis oksidasi yaitu Platinum. Plutonium, nikel, Mangan, Chromium dan oksidanya dari logam-logam tersebut. Sedangkan untuk beberapa logam yang diketahui sebagai katalis reduksi, adalah besi, tembaga, nikel paduan dan oksida dari bahan-bahan tersebut. Di samping itu masih ada logam katalis yang lebih murah, mudah dikerjakan dan mudah didapat untuk dijadikan catalityc converter antara lain : $\mathrm{CuO} /$ zeolite alam, $\mathrm{Cu}-\mathrm{Al} 2 \mathrm{O} 3$, 
$\mathrm{Cu}, \mathrm{Mn}, \mathrm{Mg}$ dan Zeolit Alam, Catalytic Converter jenis ini mampu mengurangi emisi gas buang (CO, HC,Nox) cukup tinggi antara 16\% sampai $80 \%$.

Dari referensi diatas, rata-rata variable yang digunakan untuk mendapatkan hasil perbandingan adalah dengan menggunakan variasi ukuran dari objek yang diteliti. Oleh karena referensi tersebut penelitian kali ini bertujuan mencari perbandingan unjuk kerja mesin, dengan mengganti komponen pipa gas buang menggunakan material yang memiliki sifat katalis oksidasi, serta menambahkan komponen AIS yang terkoneksi dengan pipa gas buang tersebut, sehingga ke depannya peneliti-peneliti lain maupun perusahaan otomotif dapat memperkirakan material dan konstruksi yang cocok untuk menekan emisi gas buang serta mengoptimalkan unjuk kerja mesin.

\section{METODE}

\subsection{Bahan dan Material}

Pada penelitian ini bahan yang digunakan untuk pembuatan pipa gas buang modifikasi adalah material Tembaga $(\mathrm{Cu})$ dan Aluminium (Al) dengan diameter $35 \mathrm{~mm}$ dan ketebalan yang sama yaitu $1 \mathrm{~mm}$, serta komponen AIS dengan konstruksi 3 lubang.

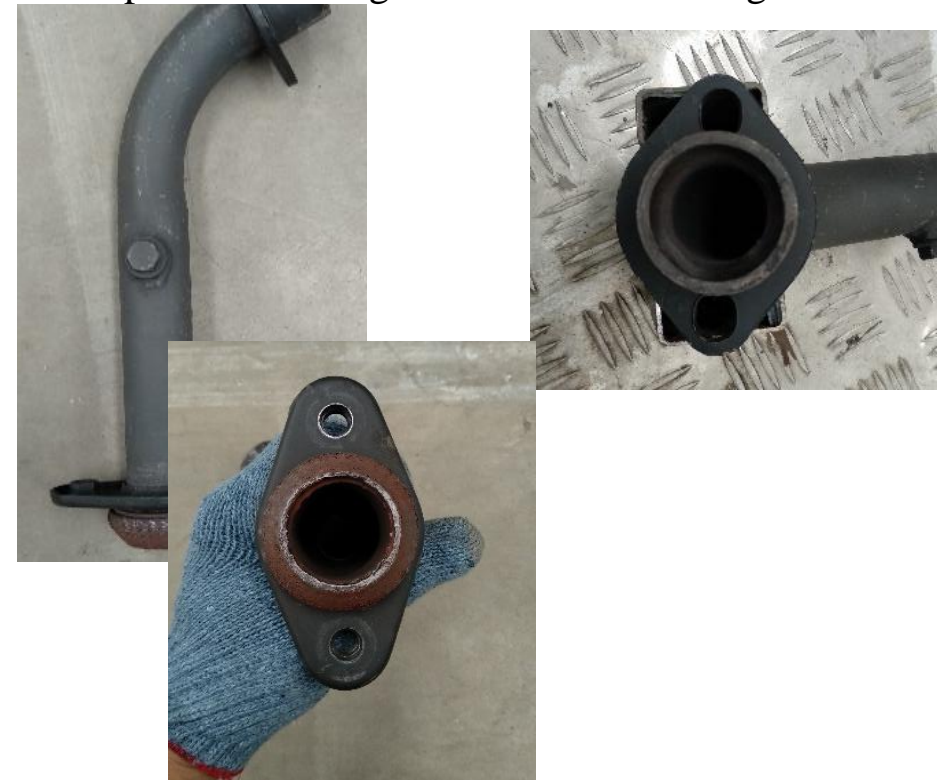

Gambar 1. Konstruksi Pipa Gas Buang Standart

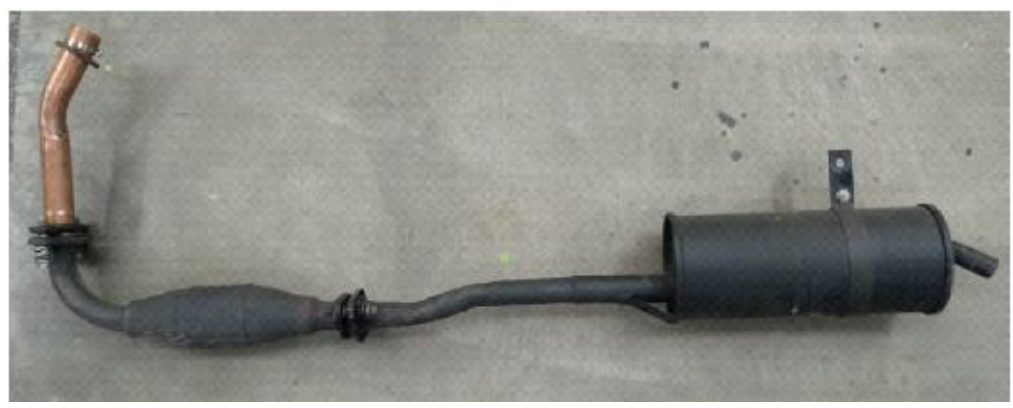

Gambar 2. Konstruksi Pipa Gas Buang Berbahan Tembaga 


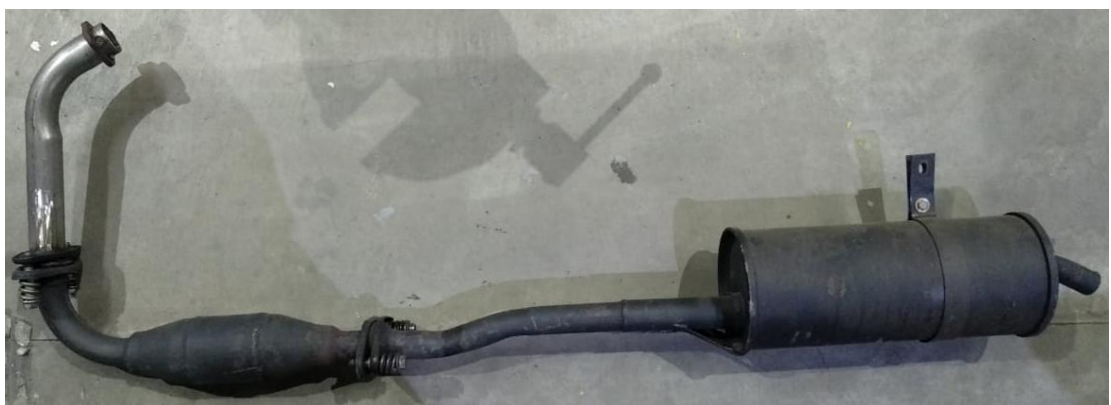

Gambar 3. Konstruksi Pipa Gas Buang Berbahan Aluminium

Tabel 1. Spesifikasi dari material Tembaga dan Aluminium

\begin{tabular}{ccc}
\hline Spesifikasi & Tembaga & Aluminium \\
\hline Diameter Luar & $35 \mathrm{~mm}$ & $35 \mathrm{~mm}$ \\
Tebal & $1 \mathrm{~mm}$ & $1 \mathrm{~mm}$ \\
Sudut Bending & $60^{\circ}$ & $60^{\circ}$ \\
Massa Jenis & $8,96 \mathrm{~g} / \mathrm{cm}^{3}$ & $2,7 \mathrm{~g} / \mathrm{cm}^{3}$ \\
Panas jenis & $400 \mathrm{j} / \mathrm{kg}^{\circ} \mathrm{C}$ & $882 \mathrm{j} / \mathrm{kg}^{\circ} \mathrm{C}$ \\
Titik Lebur & $1085^{\circ} \mathrm{C}$ & $660,3^{\circ} \mathrm{C}$ \\
\hline
\end{tabular}

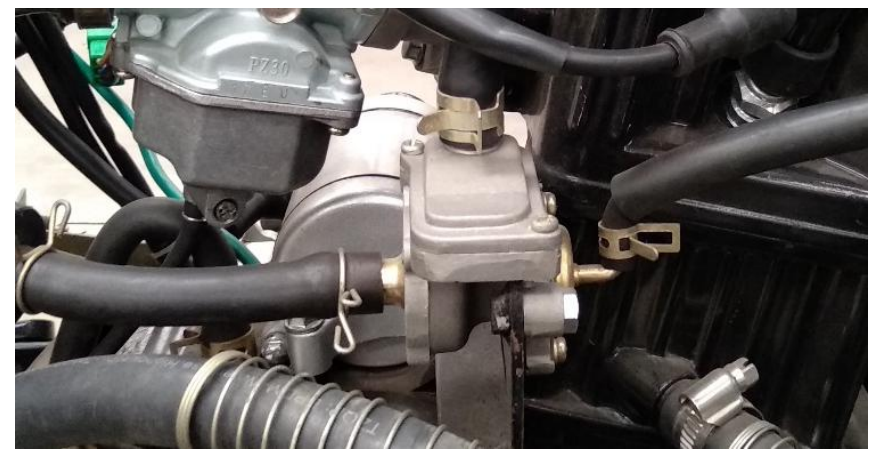

Gambar 4. Konstruksi Pipa Gas Buang

Unit kendaraan yang digunakan adalah Motor Roda Tiga merk PowerAce dengan mesin bakar 4 langkah berkapasitas 200cc, yang memiliki tipe OHC (Overhead Camshaft).

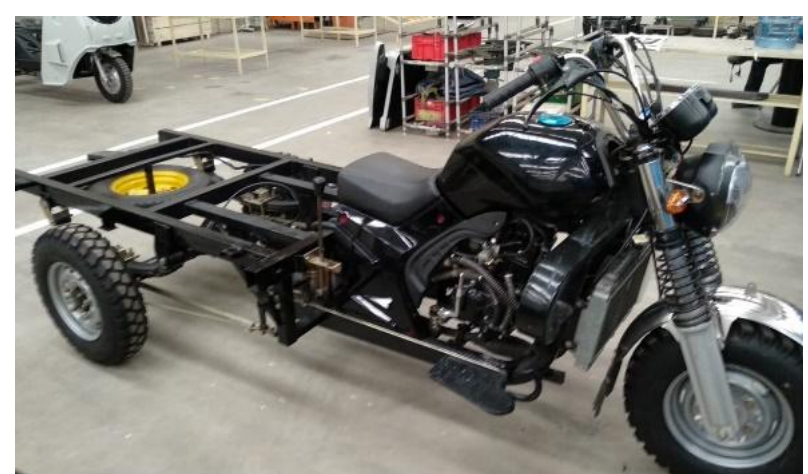

Gambar 5. Motor Roda 3 PowerAce

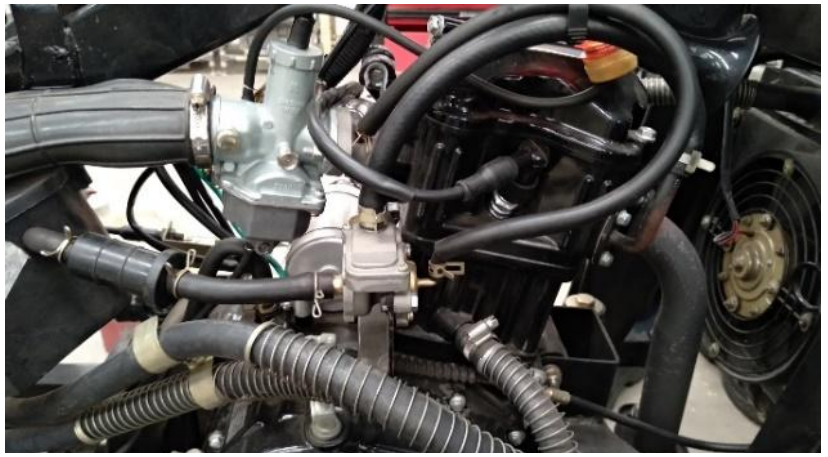

Gambar 6. Mesin 200cc 
Komponen AIS yang digunakan memiliki 3 lubang yang memiliki fungsi sebagai saluran masuk dan saluran keluar. Lubang masuk disambungkan dengan air filter yang berfungsi menarik udara bersih, serta dua lubang keluar berfungsi mengarahkan udara ke intake manifold untuk meneruskan udara segar kedalam ruang bakar dan ke dalam exhaust manifold untuk menekan kadar emisi gas buang. Pipa exhaust manifold berbahan tembaga dan aluminium dibentuk sesuai dengan ukuran exhaust manifold dengan material standar seperti gambar 5 .

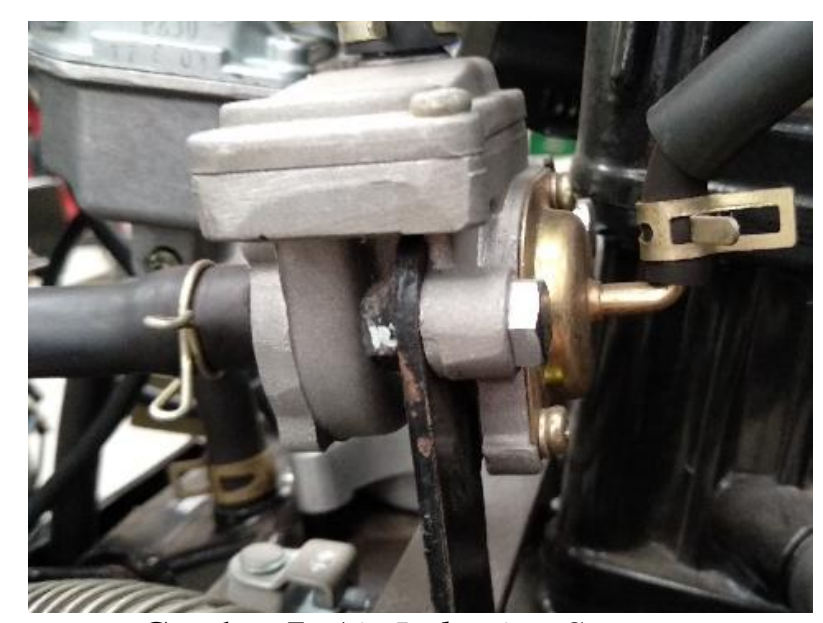

Gambar 7. Air Induction System

\subsection{Perhitungan}

Persamaan yang digunakan dalam penelitian ini yaitu rumus untuk mencari banyaknya konsumsi bahan bakar yang digunakan

1. Perhitungan Konsumsi Bahan (FC)

$$
F C=\frac{V f \times 3600}{t \times 1000}[\mathrm{~L} / \mathrm{h}]
$$

Dimana:

$$
\begin{array}{ll}
\mathrm{FC} & =\text { Fuel Consumption }(\mathrm{L} / \mathrm{h}) \\
\mathrm{V}_{\mathrm{f}} & =\text { Volume Konsumsi }(\mathrm{mL}) \\
\mathrm{t} & =\text { Waktu Konsumsi }(\mathrm{s})
\end{array}
$$

\subsection{Pengukuran}

Pengukuran emisi gas buang dilakukan dengan menggunakan gas analyzer portable dengan merek Nahua NHA-502EN yang dapat mengukur kadar gas HC, CO, NOx. Diameter probe yang di gunakan adalah sebesar $20 \mathrm{~mm}$. Probe dimasukan kedalam lubang muffler sedalam $300 \mathrm{~mm}$ untuk mendapatkan hasil yang akurat. Sebelum dilakukan pengukuran terhadap gas buang, gas analyzer dipanaskan selama 3-8 menit. 


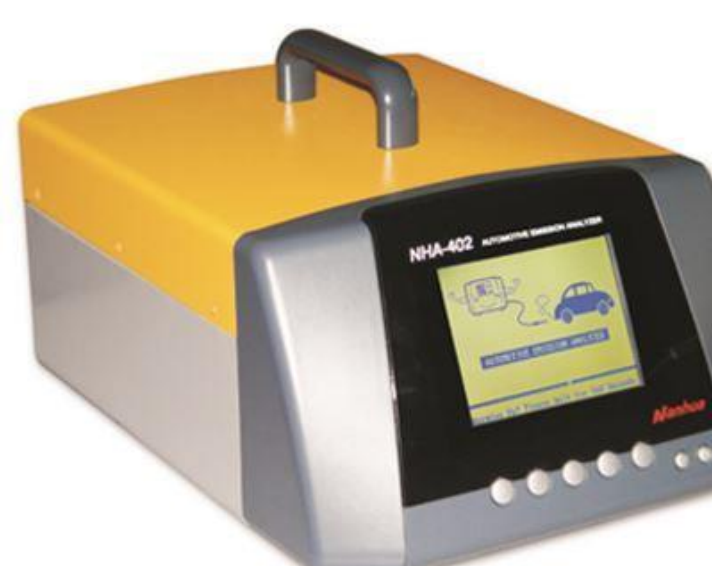

Gambar8. Mesin Uji Emisi Portable $\mathrm{Na}$ hua NHA-502EN

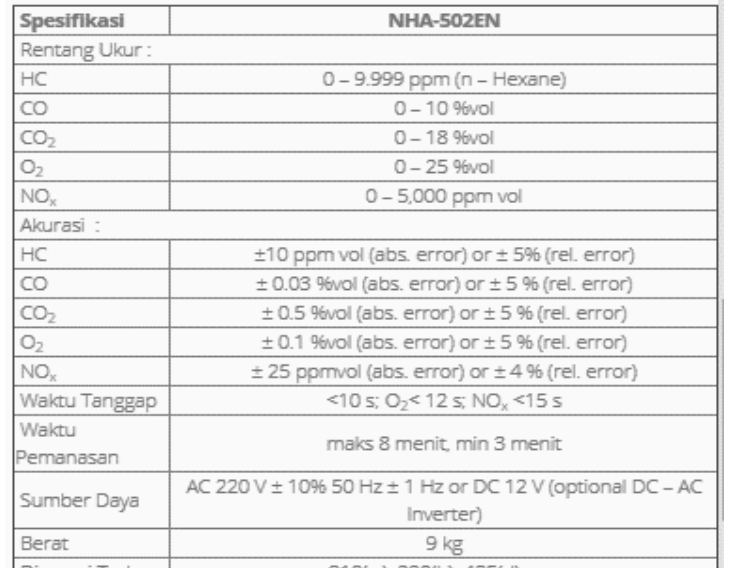

Gambar 9. Gambar Tabel Spesifik asi gas analyzer NHA-502EN

Untuk pengukuran penggunaan bahan bakar dilakukan dengan menggunakan gelas takar dengan volume awal bahan bakar yang disediakan pada tiap pengujian sebesar 200ml. lalu dimasukan kedalam wadah silinder yang terhubung ke karburator, setelah dilakukan pengujian selama 30 menit akan diketahui volume akhir. Dari data tersebut dapat diketahui banyaknya bahan bakar yang digunakan ada tiap pengujian dengan mengurangi volume awal dengan volume akhir, lalu akan dihitung fuel consumption dari tiap pengujian dengan dengan satuan liter/jam.

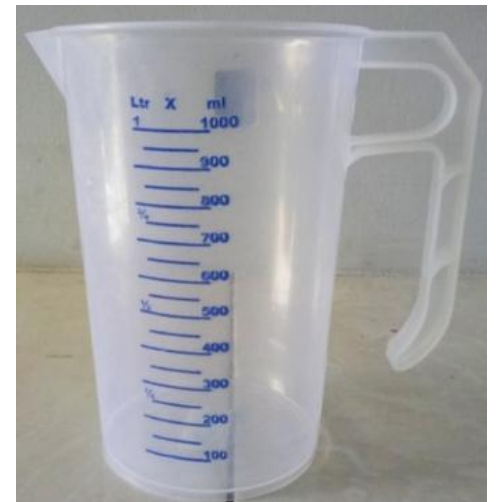

Gambar 10. Wadah Takar untuk bahan bakar

\section{HASIL DAN PEMBAHASAN}

\subsection{Gambar dan Tabel}

Ketiga Desain rancangan pipa gas buang tersebut dirakit pada mesin motor tersebut dengan posisi yang sama dengan kondisi normal. Mesin dipanaskan pada suhu kerja mesin normal yaitu $80-90^{\circ} \mathrm{C}$ lalu dilakukan pengujian masing-masing selama 30 menit. Untuk pengujian emisi sendiri didapatkan hasil sebagai berikut:

Tabel 2. Hasil Pengujian Emisi Gas Buang

\begin{tabular}{lclccccccc}
\hline Spesifikasi & Tipe & RPM & 1500 & 2000 & 2500 & 3000 & 3500 & 4000 & 4500 \\
& Uji & & & & & & & & \\
Pipa Standar & Tipe 1 & HC (ppm) & 240 & 215 & 170 & 142 & 141.6 & 105.1 & 68.6 \\
Tanpa AIS & & CO (\%) & 4.76 & 4.55 & 4.25 & 4.15 & 3.5 & 3.46 & 3.36 \\
& & CO2 (\%) & 5.6 & 5 & 2.6 & 2.85 & 2.98 & 2.95 & 2.93 \\
& & NO (ppm) & 25 & 23 & 32 & 55 & 60 & 65 & 140 \\
\hline
\end{tabular}




\begin{tabular}{cllccccccc}
\hline Pipa Standar & Tipe 2 & HC (ppm) & 69 & 105 & 78 & 46 & 67 & 67 & 86 \\
(Galvanis) + & & CO (\%) & 1.64 & 2.46 & 2.12 & 1.19 & 1.64 & 1.64 & 2.1 \\
AIS & & CO2 (\%) & 2.75 & 3.47 & 3.02 & 2.64 & 2.93 & 2.93 & 2.74 \\
& & NO (ppm) & 29 & 28 & 32 & 38 & 37 & 60 & 152 \\
Pipa & Tipe 3 & HC (ppm) & 44 & 70 & 46 & 33 & 52 & 13 & 39 \\
Tembaga + & & CO (\%) & 0.04 & 0.03 & 0.03 & 0.02 & 0 & 0 & 0 \\
AIS & & CO2 (\%) & 6.3 & 6.7 & 6.4 & 7.1 & 8 & 9 & 7.9 \\
& & NO (ppm) & 53 & 52 & 53 & 42 & 63 & 71 & 45 \\
Pipa & Tipe 4 & HC (ppm) & 10,5 & 1.34 & 51 & 12 & 82 & 100 & 60 \\
Aluminium + & & CO (\%) & 0.01 & 0.14 & 0.37 & 0.1 & 0.02 & 0.02 & 0.01 \\
AIS & & CO2 (\%) & 6.7 & 5.6 & 6.1 & 7.2 & 6.7 & 7.4 & 11.2 \\
& & NO (ppm) & 35 & 26 & 34 & 48 & 80 & 65 & 67 \\
\hline
\end{tabular}

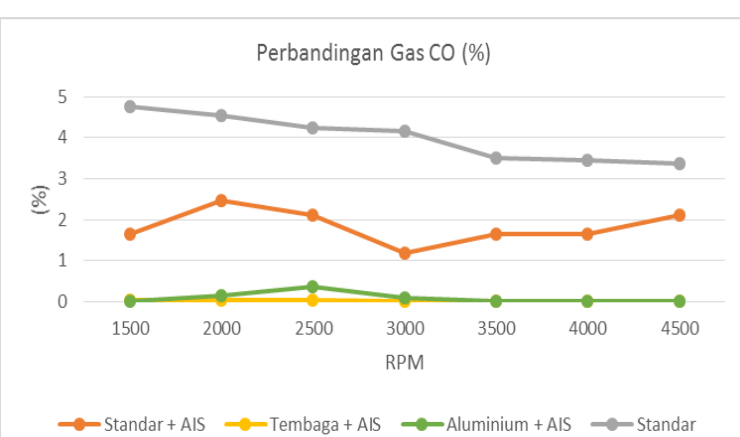

Pengujian Gas CO2

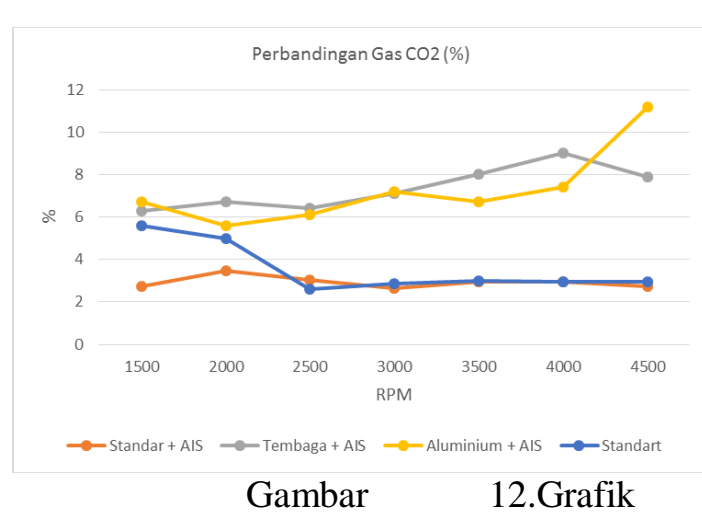

Dari data diatas dapat dilihat hasil dari kadar gas CO yang dihasilkan dari masing masing tipe uji yang di cari berdasarkan variable rpm , yaitu $1500-4500$. Dari data tersebut rata-rata gas $\mathrm{CO}$ tertinggi dihasilkan oleh uji 1 dengan rata - rata gas $\mathrm{CO}$ sebesar $4.0 \%$, diikuti menggunakan pipa dengan uji 2 dengan rata-rata sebesar $1.8 \%$. Kadar Gas CO dari uji 3 dan uji 4 memiliki kadar gas CO dengan rata-rata dibawah 1\%. Rata - rata terendah dihasilkan tipe uji 3 yaitu sebesar $0.017 \%$. Pada putaran rendah secara keseluruhan pipa dengan material tembaga dan aluminium memiliki hasil yang lebih baik dalam menurunkan kadar gas CO dibandingkan dengan kondisi standar (uji 1). Pada putaran rendah gas CO yang dihasilkan sudah mencapai angka dibawah $1 \%$, ini dikarenakan material uji 3 dan uji 4 memiliki nilai oksidasi terhadap gas $\mathrm{CO}$ yang lebih baik sehingga mempercepat penurunan kadar CO serta penambahan Oksigen melalui AIS membantu reaksi menjadi lebih sempurna. Pada putaran 2500 rpm tipe uji 4 mengalami kenaikan kadar gas CO, ini dapat disebabkan karena perbandingan udara dan bahan bakar tidak seimbang sehingga reaksi $\mathrm{C}$ tidak semua terikat, namun secara keseluruhan nilainya masih lebih baik karena masih dibawah ambang batas yaitu sebesar $4,5 \%$.

Untuk gas $\mathrm{CO}_{2}$ yang dihasilkan menunjukkan hasil yang cukup berbeda. Gas $\mathrm{CO}_{2}$ dalam gas buang menandakan kesempurnaan pembakaran yang terjadi pada ruang bakar, dimana semakin tinggi nilai $\mathrm{CO}_{2}$-nya maka pembakaran yang terjadi semakin mendekati sempurna begitupun sebaliknya semakin rendah kadar $\mathrm{CO}_{2}$ maka pembakaran yang terjadi semakin jauh dari sempurna. Nilai gas $\mathrm{CO}_{2}$ yang dihasilkan pada keempat pengujian menunjukkan hasil bahwa pembakaran pada tipe uji 1 dan uji 2 memiliki nilai yang rendah jika dibandingkan dengan tipe uji 3 dan 4. Penggunaan AIS memberikan bantuan udara bersih untuk mempercepat proses oksidasi gas $\mathrm{CO}$ yang dihasilkan dari pembakaran, sehingga 
kadar gas $\mathrm{CO}_{2}$ menurun. Hal ini juga didukung karena adanya kemampuan dari material tembaga dan aluminium dalam proses oksidasi tersebut. Tipe uji 3 dan 4 memiliki rata-rata kadar gas $\mathrm{CO}_{2}$ sebesar $7.3 \%$ dan $7.2 \%$.

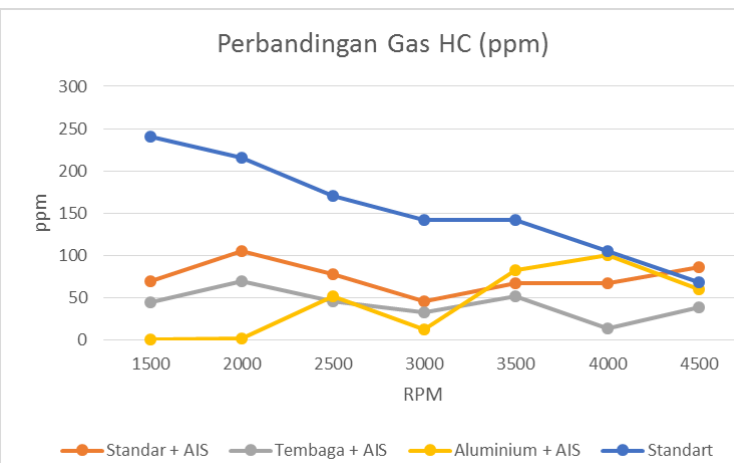

Gambar 13.Grafik Pengujian Gas HC Pengujian Gas NOx

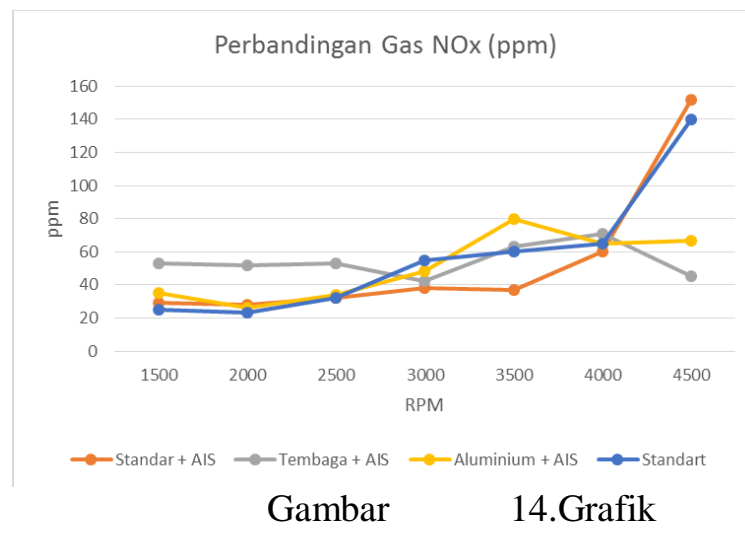

Hasil yang bervariasi juga didapatkan pada emisi gas HC dan NOx. Dari grafik di atas didapatkan data untuk rata-rata gas $\mathrm{HC}$ terendah dihasilkan tipe uji 3 yaitu sebesar 53.7 ppm (part per million) dengan nilai $\mathrm{HC}$ terendah didapatkan pada putaran 4000. Menurunnya kandungan emisi gas HC pada sepeda motor dikarenakan sifat dari kimia tembaga yaitu dapat bereaksi dengan oksigen membentuk $\mathrm{CuO}$ sehingga gas buang hidrokarbon apabila melewati tembaga panas akan beroksidasi dengan oksigen menjadi $\mathrm{H} 2 \mathrm{O}$ hal ini sejalan menurut Emel Seran (2017) ${ }^{[7]}$ yang mengemukakan bahwa "Pada kondisi yang istimewa yakni pada suhu sekitar $300^{\circ} \mathrm{C}$ tembaga dapat bereaksi dengan oksigen membentuk $\mathrm{CuO}$ yang berwarna hitam. Secara keseluruhan dari ke empat tipe uji, penggunaan AIS sangat membantu penurunan kadar HC pada putaran awal, karena udara yang dinput ke intake manifold dan exhaust manifold membantu mempercepat bahan bakar ke nilai ekonomis.

Pada grafik NOx data yang terlihat pada putaran rendah keempat tipe uji menghasilkan NOx dibawah 60 ppm. Tipe uji yang memiliki nilai rata - rata NOx terendah adalah tipe Uji 4 dimana menghasilkan rata-rata NOx sebesar 50,7 ppm. Pada putaran $4000 \mathrm{rpm}$ ke atas untuk tipe uji 1 dan 2 menghasilkan kenaikan gas NOx yang cukup tinggi di angka 140 dan 152 ppm, hal ini disebabkan karena adanya panas dari pembakaran mesin yang menyebabkan lonjakan pada putaran 4000 - 4500. Kemampuan reaksi yang kurang baik dari pipa galvanis dalam mereduksi gas menjadi faktor pendukung terjadinya lonjakan gas NOx, karena pada putaran tinggi pula udara bersih dari AIS membuat pembakaran menjadi lebih sempurna sehingga panas yang dihasilkan meningkat. Dan memberi efek terhadap lonjakan gas NOx.

Dari sisi penggunaan bahan bakar, banyaknya bahan bakar yang digunakan selama proses pengujian dilakukan dengan mengukur volume bahan bakar yang digunakan dalam waktu selama 30 menit dan range rpm yang digunakan sama yaitu 1500 - 4500 setiap variable rpm dilakukan pengujian selama \pm 7 menit. Dari 4 pengujian tersebut data yang didapatkan adalah sebagai berikut 


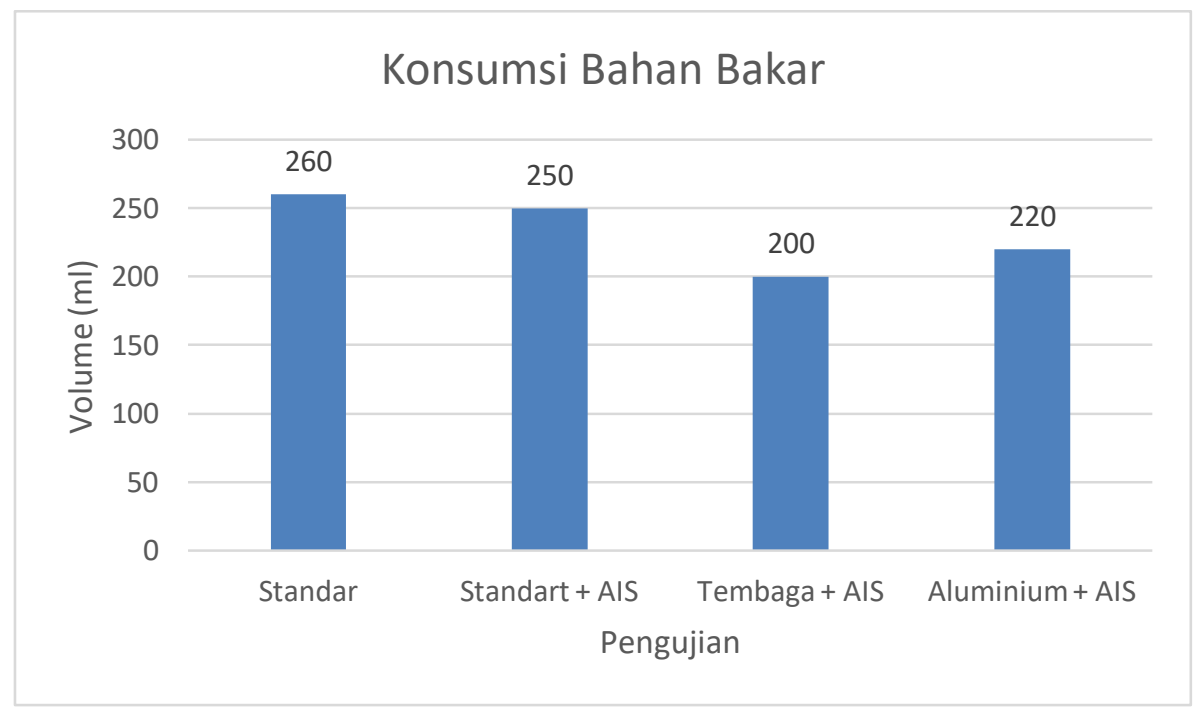

Gambar 15. Grafik Konsumsi Bahan Bakar / 30 menit

Untuk mendapatkan volume bahan bakar yang digunakan per jam maka dilakukan perhitungan fuel consumption dari keempat data diatas sebagai berikut:

- Uji 1 (Standar)

$$
F C=\frac{260 \times 3600}{1800 \times 1000} \quad=0,52 \text { liter/jam }
$$

- Uji 2 (Standar + AIS)

$$
F C=\frac{250 \times 3600}{1800 \times 1000} \quad=0,5 \text { liter } / \text { jam }
$$

- Uji 3 (Tembaga + AIS)

$$
F C=\frac{200 \times 3600}{1800 \times 1000} \quad=0,4 \text { liter } / \mathrm{jam}
$$

- Uji 4 (Aluminium + AIS)

$$
F C=\frac{220 \times 3600}{1800 \times 1000} \quad=0,44 \text { liter } / \text { jam }
$$

Bahan bakar yang digunakan pada tiap pengujian sama yaitu menggunakan pertalite. Pada data tersebut menunjukkan bahwa penggunaan pipa dengan bahan tembaga memberikan nilai $S F C$ yang lebih baik dibandingkan dengan tipe lainnya yaitu 0,4 liter/jam, sedangkan konsumsi bahan bakar paling boros didapatkan dari kondisi konstruksi standar yaitu 0,51 liter/jam. Pada data diatas hasil uji 2 sampai uji 4 menunjukkan efek dari penggunaan komponen AIS berdampak terhadap penurunan temperatur dan tercapainya kesempurnaan pembakaran, sehingga bahan bakar yang digunakan tidak terlalu kaya dan menyebabkan berkurangnya konsumsi dari bahan bakar itu sendiri. 


\section{SIMPULAN}

Berdasarkan pengolahan dan analisis data penelitian yang telah dilakukan, dapat diambil beberapa kesimpulan bahwa penggunaan material pipa gas buang dengan material logam non ferro memberikan rata - rata penurunan terhadap gas $\mathrm{HC}$ dan $\mathrm{CO}$ pada putaran tertentu, dimana pada dasarnya gas ini yang menjadi gas buang yang cukup berbahaya terhadap tubuh manusia. Namun di sisi yang lain Gas $\mathrm{CO}_{2}$ pada uji 3 dan uji 4 memiliki nilai yang tinggi, karena pembakaran lebih sempurna mulai dari putaran rendah sampai dengan putaran tinggi.

Percobaan diatas juga menunjukkan aliran udara segar dengan air induction system menuju intake manifold dan exhaust manifold memberikan efek yang cukup signifikan terhadap reaksi gas khususnya di saluran gas buang, yang memberikan dampak terhadap kesempurnaan pembakaran yang terjadi di dalam mesin, yang pada akhirnya menekan volume penggunaan bahan bakar yang digunakan untuk proses pembakaran.

Pemilihan konstruksi terhadap pipa gas buang dengan sudut $60^{\circ}$ tentunya memberikan dampak yang baik terhadap emisi serta penggunaan bahan bakar, namun ke depannya masih perlu diteliti berapa sudut exhaust manifold yang paling efektif untuk mendukung unjuk kerja mesin, maka dari itu perlu dilakukan penelitian terhadap sudut pipa gas buang dengan material non ferro dengan komponen air induction system.

\section{UCAPAN TERIMA KASIH}

Ucapan terima kasih disampaikan untuk :

- $\quad$ Universitas Kristen Indonesia yang memfasilitasi penulisan jurnal ini.

- $\quad$ PT. Dharma Polimetal yang memfasilitasi pencarian data penelitian.

- Universitas Udayana yang sudah memberikan tempat untuk mempublikasikan penelitian penulis.

- $\quad$ Kepada semua pihak yang telah membantu baik secara langsung maupun tidak langsung.

\section{DAFTAR PUSTAKA}

[1] "Badan Pusat Statistik." https://www.bps.go.id/LinkTableDinamis/view/id/1133 (accessed Mar. 16, 2021).

[2] A. Sanata and I. Sholahuddin, "RANCANG BANGUN KNALPOT INOVATIF BERTEKNOLOGI CATALYTIC CONVERTER DENGAN LOGAM KATALIS BAJA KARBON RENDAH SEBAGAI PEREDUKSI POLUTAN GAS BUANG KENDARAAN BERMOTOR."

[3] R. B. S. Majanasastra, D. Febriantoro, and M. I. Mahfud, "ANALISIS PENGARUH PANJANG PIPA HYDROCARBON CRACKING SYSTEM (HCS) TERHADAP PERFORMA MESIN SEPEDA MOTOR," J. Ilm. Tek. MESIN, vol. 8, no. 1, pp. 45-49, 2020.

[4] J. Irawan, M. Martias, and M. Nasir, "ANALISIS PENGARUH PENGGUNAAN AIR INDUCTION SYSTEM (AIS) TERHADAP KONSUMSI BAHAN BAKAR DAN EMISI GAS CO YAMAHA MIO," Automot. Eng. Educ. J., vol. 1, no. 2, 2014.

[5] S. Sarwuna, W. Ruslan, and I. Setiawan, "KAJIAN SIMULASI PENGARUH TEKANAN BALIK GAS BUANG TERHADAP KINERJA MESIN SEPEDA MOTOR EMPAT LANGKAH 135CC," Teknobiz J. Ilm. Program Studi Magister Tek. Mesin, vol. 7, no. 3, pp. 143-149, 2017.

[6] M. S. C, "PENGARUH METALLIC CATALYTIC CONVERTER TEMBAGA BERLAPIS KROM DAN AIR INDUCTION SYSTEM (AIS) TERHADAP REDUKSI EMISI GAS BUANG YAMAHA NEW JUPITER MX," J. Pendidik. Tek. Mesin, vol. 3, 
no. 02, Art. no. 02, 2014, Accessed: Mar. 16, 2021. [Online]. Available: https://jurnalmahasiswa.unesa.ac.id/index.php/jurnal-pendidikan-teknikmesin/article/view/11134.

[7] B. Hariyanto, A. Wahab, and U. Lesmanah, "PENGARUH CATALYTIC CONVERTER ALUMUNIUM TIPE SARANG LEBAH TERHADAP EMISI GAS BUANG MOTOR DIESEL," J. Tek. Mesin, vol. 11, no. 01, pp. 7-11, 2019. 